\title{
The Effect of a Complex Multi-modality Ayurvedic Treatment in a Case of Unknown Female Infertility
}

\author{
Christian Kessler ${ }^{a, b} \quad$ Elmar Stapelfeldt $^{\mathrm{a}} \quad$ Andreas Michalsen $^{\mathrm{a}, \mathrm{b}} \quad$ Ingrid Kowalcek $^{\mathrm{c}}$ \\ Ludwig Kronpaß ${ }^{\mathrm{d}}$ Anand Dhruva ${ }^{\mathrm{e}}$ \\ a Immanuel Hospital Berlin, Department of Internal and Complementary Medicine, Berlin, Germany; \\ ${ }^{b}$ Charité - University Medical Centre, Institute of Social Medicine, Epidemiology and Health Economics, Berlin, Germany; \\ 'Interdisciplinary Research Institute for Womens' Health, Lübeck, Germany; \\ ${ }^{d}$ Hospital Rotthalmünster, Department for Gynecology and Obstetrics, Rotthalmünster, Germany; \\ e University of California San Francisco, Osher Center for Integrative Medicine, San Francisco, CA, USA
}

\section{Keywords}

Ayurveda $\cdot$ Ayurvedic · Traditional Indian Medicine .

Whole Medical System · Female Infertility · Reproductive Medicine ·

Complementary Medicine $\cdot$ Integrative Medicine

\section{Summary}

Background: Treatment of female infertility has been growing globally in recent years. In spite of improvements in medical strategies and the improved outcomes for infertile couples, treatment attempts remain largely unsuccessful. A growing number of patients pursue complementary and alternative medicine treatment options like Ayurveda that offers a variety of inpatient and outpatient treatments for infertility. Case Report: A case of a 38 year-old woman with infertility of unknown origin is presented. She received 18 conventional fertility treatments in 5 different fertility centers and 3 different countries. After several complications, the patient quitted conventional treatment and admitted to an Ayurvedic outpatient clinic where she received a complex Ayurvedic treatment, which included botanicals, dietary and lifestyle advice, manual therapy, yoga, and spiritual elements. The patient then became pregnant and gave birth to a healthy boy in 2012. Conclusions: Ayurveda may be a useful complementary option in the case of futile conventional treatment attempts in female infertility. Nevertheless, the evidence base for Ayurvedic interventions remains weak and requires well-designed clinical trials. This case raises some questions, such as whether the exposure to a large number of assisted reproduction procedures can lead to more health problems than health benefits. The Ayurvedic approach to fertility strives first to improve the health of the patient leading to a higher likelihood of pregnancy. As this is a case report, we are not able to exclude temporal factors stimulating the pregnancy. However, the chronology suggests that this approach might have been an important factor in the eventual pregnancy.

(C) 2015 S. Karger GmbH, Freiburg

\author{
Schlüsselwörter \\ Ayurveda . Ayurvedisch . Traditionelle indische Medizin . \\ Unfruchtbarkeit · Reproduktionsmedizin · Komplementärmedizin . \\ Integrative Medizin
}

\section{Zusammenfassung}

Hintergrund: Die Anwendung reproduktionsmedizinischer Maßnahmen zur Behandlung des unerfüllten Kinderwunsches hat in den letzten Jahren weltweit erheblich an Bedeutung gewonnen. Trotz Fortschritten bei therapeutischen Ansätzen und zunehmend besseren Behandlungsergebnissen bleiben die reproduktionsmedizinischen Behandlungen bei unfruchtbaren Paaren häufig erfolglos. Eine zunehmende Anzahl an Patientinnen verfolgt daher komplementäre Ansätze wie beispielsweise Ayurveda, das eine Reihe an ambulanten und stationären Therapieoptionen bei unerfülltem Kinderwunsch bietet. Fallbericht: Berichtet wird der Fall einer 38-jährigen Frau mit der Diagnose einer sekundären idiopathischen Sterilität. Insgesamt wurden bei ihr 18 Zyklen der assistierten Reproduktion $(11 \times$ IVF, $7 \times$ ICSI) in 5 unterschiedlichen Institutionen sowie 3 verschiedenen Ländern durchgeführt. Nach diversen Komplikationen brach sie die Therapien jedoch ab und nahm eine komplexe ambulante Ayurveda-Behandlung an einer naturheilkundlichen Spezialklinik in Anspruch. Die Ayurveda-Verfahren umfassten Behandlungen mit pflanzlichen Präparaten, Ernährungs- und Lebensstilmaßnahmen, manuelle Therapien, Yoga und spirituelle Elemente. Die Patientin wurde schwanger und brachte 2012 einen gesunden Sohn zur Welt. Schlussfolgerungen: Ayurveda kann eine nützliche komplementärmedizinische Option sein, falls konventionelle Behandlungsmöglichkeiten nicht anschlagen. Jedoch ist die Evidenzbasis für Ayurveda-Therapien in diesem Bereich noch schwach und benötigt weitere, qualitativ hochwertige klinische Studiendaten. Der vorliegende Fall wirft einige Fragen auf wie beispielsweise die nach Nebenwirkungen von langfristiger konventioneller Polypragmasie bei Fruchtbarkeitsbehandlungen. Der AyurvedaAnsatz bei Fertilitätsbehandlungen zielt auf eine Verbesserung des gesundheitlichen Gesamtzustands ab und als Resultat dessen auf eine Steigerung der Wahrscheinlichkeit des Eintretens einer Schwangerschaft. Da es sich hierbei um einen Fallbericht handelt, können zeitliche Zufallsfaktoren, die zu einer Schwangerschaft geführt haben könnten, nicht ausgeschlossen werden. Jedoch lässt der Behandlungsverlauf insgesamt darauf schließen, dass der Ayurveda-Ansatz für das erfreuliche Endergebnis eine Rolle gespielt haben könnte.

\section{KARGER \\ Fax +497614520714




\section{The Conventional Biomedical Perspective on Unexplained Female Infertility}

The World Health Organization (WHO) defines infertility as the inability to conceive despite regular sexual intercourse for more than 12 months [1]. In women, advanced age, endocrine conditions, tubarian, uterine, or endometrium-related conditions are potential causes. In men, infertility can occur due to poor sperm quality and spermatogenesis as well as erectile dysfunction. In both sexes, psychosomatic aspects are important. Unexplained infertility refers to a diagnosis made in couples in whom standard investigations including semen analysis, ovulation testing, and tubal patency yield normal results. This accounts for $25-30 \%$ of all couples undergoing reproductive procedures [2]. The evaluation of unexplained female infertility includes patient history, gynecological examination, monitoring of the basal temperature, vaginal and cervical microbiological analysis, vaginal ultrasound, hormonal analysis (i.e. follicle stimulating hormone (FSH), luteinizing hormone (LH), prolactine, testosterone, dehydroepiandrosterone sulfate (DHEAS), and thyroid-stimulating hormone (TSH)) and hysteroscopic chromopertubation to visualize the fallopian tubes, and semen analysis $[3,4]$.

Ovarian treatment options include the use of: (a) gonadotropins in the case of hypogonadotropic ovarian failure [5] (b) Selective Estrogen Receptor Modifiers (SERMs) like clomiphene in the case of hypogonadotropic ovarian failure [6], (c) prolactin inhibitors in the case of hyperprolactinemia [7], (d) weight reduction and metformin in the case of hyperandrogenemia and Polycystic Ovarian Syndrome (PCOS) $[8,9]$, (e) progestogens in case of endometriosis, and (f) pulsatile Gonadotropin Releasing Hormone (GnRH) pump in case of hypothalamic ovarian failure [10]. Tubarian causes can be treated by microsurgery or in vitro fertilization (IVF) [11]; uterine or endometrium causes by hysteroscopical-surgical measures [12]; in case of endometriosis, surgical measures and adhesiolysis can be considered. Andrological options may include hormonal therapy, artificial insemination, and intracytoplasmic sperm injection (ICSI). [13] Lifestyle counseling can also be included in multimodal treatment strategies [14]. In case of idiopathic or psychosomatic causes, psychotherapy and complementary and alternative medicine (CAM) measures can also be considered as treatment options.

\section{Assisted Reproduction}

The time from IVF with assisted reproduction to the birth of a child can entail several years and can go along with frustration due to failed treatments. The first pregnancy after assisted reproduction was noted in 1973, ending in a miscarriage, though. A second pregnancy was recorded in 1976, however, the embryo was embedded in the fallopian tubes and had to be surgically removed. In 1977, a study with 68 women was launched, ending up with one woman having a deformed, still-born child, and another woman having an abortion. Altogether, up to the birth of the first IVF child, 200 embryos were transferred. In 1978, the first child was born following assisted reproduction [15-18]. The general consensus was positive and regarded the assisted reproduction as helpful and humane. Reflecting similar global trends, assisted reproductive treatment (ART) has become increasingly popular in the past 30 years in Germany [18].

Medical technology has improved the outcomes for infertile couples. Usually, hormonal stimulation is performed. During the natural process of the menstrual cycle, only one follicle matures up to ovulation of a fertilized oocyte. Therefore, hyperstimulation is recommended in order to produce a greater quantity of mature follicles and thus several oocytes. There are several methods of therapy available. The current follicular hormone levels and the sonographic size of the follicle are important parameters in determining the hyperstimulation treatment. Ovulation is induced by administering 10,000 $\mathrm{mIU} / \mathrm{mL}$ human chorionic gonadotropin (hCG). The follicle biopsy is performed under sonographic guidance. Each individual follicle is aspirated based on an identification of the sonographic topography in the pelvic region. The aspirates are then placed on a glass dish and examined under a stereo-microscope; the oocytes are isolated and assessed for their degree of maturity. Following preparation of the ejaculate, insemination takes place. A maximum of 3 embryos are transferred to the uterus, followed by insemination within $40-48 \mathrm{~h}$. The embryo, at this point, is in the four- to eight-cell stage.

In addition to IVF with tubar factor, ICSI has also been introduced in cases of more complex male subfertility [17] and offers a symptomatic form of treatment. One single spermatozoon is injected directly into the cytoplasm of the oocyte using a micropipette. The microinjection is administered using an invert microscope combined with phase-contrast objectives and hydraulic micromanipulators. With 100 -fold magnification the oocyte is rotated with the injection pipette until the polar body is either lying on top or bottom. In this position the oocyte is aspirated and held in the pipette before being punctured into the oocyte and the cytoplasm. The center of the oocyte must be punctured so that the oolemma in the cell is carefully and non-traumatically broken, followed by the injection of the spermatozoon.

After successful fertilization of the ovum and $48 \mathrm{~h}$ after insemination, the embryo is transferred in the two- to eight-cell stage into the uterus. In Germany it is stipulated that a maximum of $3 \mathrm{em}-$ bryos can be transferred. After transferring the embryo, implantation is no longer controllable. The ensuing 2 -week luteal phase is supported with medication (hCG or progesterone). On the day of the embryo transfer as well as on the $2 \mathrm{nd}$ and 5 th day, the patient is usually given 5,000 $\mathrm{mIU} / \mathrm{mL}$ hCG; alternatively 2 vaginal capsules of progesterone can be administered daily, especially if an overstimulation syndrome is expected.

Under IVF with intracytoplasmatic sperm injection and subsequent embryo transfer the rate of successful pregnancy is around $27 \%$; the baby take home rate is around $17 \%$ [17]. 


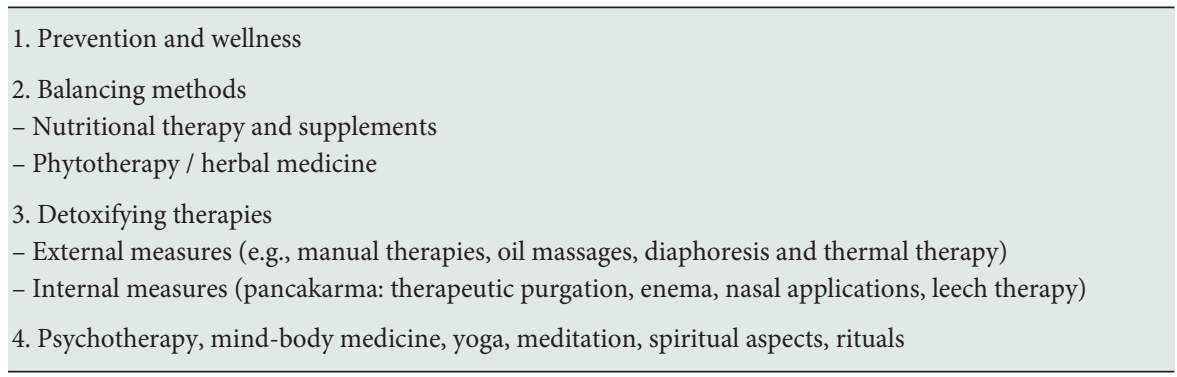

Table 2. Core features of Ayurveda

\section{Ayurveda}

Literally translated from Sanskrit, Ayurveda means 'knowledge of the life'. Ayurveda is originated in South Asia, has been practiced for thousands of years, and is one of the oldest whole medical systems (WMS) [19-22]. It is recognized by the WHO as a medical science, analogous to traditional Chinese medicine (TCM), and embodies a wealth of empirical healing knowledge. In India and some neighboring countries, Ayurvedic medicine is officially recognized and legally on a par with conventional medicine, serving more than 1.4 billion people [23-24]. The importance of Ayurveda in the modern South Asian health care framework is reflected in the following figures: in India alone, there are more than 400,000 registered physicians practicing Ayurveda [25] and more than 250 universities and colleges teaching Ayurvedic medicine systematically within 4- to 6-year university degree programs [26].

In its diagnostic and therapeutic approaches (table 1), Ayurveda is steeped in salutogenic principles $[27,28]$. Therefore and despite its age-old tradition, it is also quite modern in that primary, secondary and tertiary prevention, patient self-empowerment, and self-efficacy play crucial roles in the holistic and multidimensional alignment that Ayurveda is built upon [29]. Additionally, it focuses on individualized treatments and thus is a form of personalized medicine. Ayurveda's individual-related approaches have the potential to be successfully integrated into the Western health care framework, in particular within the context of modern integrative medical care [30]. Moreover, the constitution-based and patientcentered Ayurvedic strategies are usually associated with high patient satisfaction and, in addition to the desired main medical effect, often lead to psycho-emotional improvements and increased quality of life [31] (table 2).

Ayurveda is a WMS with a focus on both preventive and curative treatments; its complex treatment strategies focus on detecting disequilibria of the individual constitution [32-34]. In therapy and prevention the specific measures include nutritional therapy, lifestyle and mind-body medicine, detoxifying and purification processes (i.e. pancakarma), manual and physical therapies, and phytotherapy (table 1) [29].

\section{Specific Principles of Fertility Treatment in Ayurveda [32, 35-37]}

The disease entity vandhyatva is the closest approximation to unexplained infertility in the Ayurvedic nosology. Detailed diagnostic and therapeutic strategies are already mentioned in the authoritative Ayurvedic text Caraka Samhita (chapter Cikitsa-sthana, Yonivyapat) that dates to around the beginning of the Common Era.

In following centuries, specialized texts on gynecology evolved, of which the Kashyapa-Samhita is the most accepted. It offers detailed descriptions of various diseases and dedicates a complete chapter to female infertility.

Main Ayurvedic treatment goals are (1) the purification and (2) the functional optimization of 'reproductive tissues' (arthava- and shukra-dhatu) of both sexes. According to Ayurveda, reproductive health is primarily determined by the health of tissue metabolism and tissue nutrition, both being ultimate requirements for conception.

Therefore, general pancakarma purification measures usually initiate the treatment sequence. While purgation is almost always recommended, other cleansing measures are optional and may include medicated enema, emesis, and blood purification.

Based on the assessment of the patient's constitution and individual diagnostic variations the specific therapy may include items from all of the treatment categories outlined in table 1 .

Apart from these selected therapies, Ayurveda offers additional options for the treatment of infertility. In fact, therapy dedicated to the improvement of reproductive functions is represented by 1 of 8 main branches of Ayurvedic medicine (vaji-karana). Intensive long-term inpatient treatments may also be recommended, consisting of several sequential therapeutic elements which are selected according to the specific case and may also include invasive measures (e.g., intrauterine douche with medicated oils or decoctions (uttara-basti)). A description of the complete range of inpatient treatment options is beyond the scope of this review.

As Ayurveda is a holistic science, it is important to always consider the patient's overall health condition. Analogous, the unique feature of the Ayurvedic approach to fertility is that it emphasizes 
improving the overall health of the prospective parents. Fertility therefore may ensue partly due to improved overall health. This approach contrasts with the biomedical approach, which does not directly consider overall health.

\section{Case Report}

A 38 year-old Caucasian woman with an unfulfilled desire to have a second child admitted to an Ayurveda outpatient clinic in a European (EU) capital for the first time in October 2011. Additionally, she reported having problems falling asleep, recurring fevers, and a general feeling of exhaustion and tiredness. She presented as gravida 4 and para 1 at the time of her first consultation in the Ayurveda outpatient clinic. In fall 2010, the fertility experts informed her that another pregnancy would be unlikely. Between March 2007 and October 2011 she had received a total of 18 conventional Western biomedical female infertility treatments in 5 different specialized fertility centers and 3 different countries ( $2 \mathrm{EU}$ countries and USA). These included 11 IVF procedures (7 ICSI and 4 (cryo-) embryo transfers), 4 intrauterine inseminations (IUI) performed under general anesthesia due to a curved cervix uteri, 3 conventional fertility drug-only treatment attempts, and a significant number of concomitant fertility drugs including clomifen, follitropin alpha, menotropin, recombinant FSH, recombinant LH, tryptorelin, and hCG, progesteron, hydroxyprogesteronecaproate, estradiol, bromocriptine, and dienogest. She also tried bio resonance therapy, a CAM treatment. Assessment of ovulation and the fallopian tubes was performed in 2005 via hystero-contrast-salpingography showing no abnormal findings. The semen analyses of her husband performed prior to most of the IVFs yielded normal results. Polycystic ovary syndrome (PCOS) was diagnosed in 2005 given irregular menstruation cycles (30-45 days) with severe dysmenorrhea since the age of 15 , and bleeding usually lasting 8-9 days with heavy to intolerable abdominal pain, at times requiring opiods (Tramal). Parental genetic assessments were also performed in 2010 (USA) and in 2011 (EU), also without any pathological findings. Due to an expert-diagnosed overactive immune system (diagnosed in 2004) the infertility treatment was regularly accompanied by the administration of acetylsalicylic acid, prednisolone, and after the first 13 unsuccessful attempts heparin and metformin were also administered. Overall, 2 episodes of an ovarian hyperstimulation syndrome (OHSS), one mild (2009) and one severe (2008), occurred after ovarian stimulation treatment. During this time period, 3 pregnancies occurred, 2 of which ended up with miscarriages (one treated with curettage).The maximum duration of pregnancy was 10 weeks. The third pregnancy was a rare 'extra-uterine' intramural pregnancy (there are only a handful of well described cases in literature), most likely due to an embryo transfer failure. It had to be aborted by surgery in combination with an intraoperative local methotrexate (MTX) injection into the amniotic cavity and 3 subsequent systemic MTX administrations $(2 \times 50 \mathrm{mg}, 1 \times 70 \mathrm{mg})$. After MTX treatment her medical team strongly advised her against further fertilization attempts. Subsequently, she turned to a fertility center in the USA to explore the option of surrogate motherhood. However, all 3 attempts with a surrogate mother failed due to non-nidation of the fertilized ovum. The patient was receiving psychotherapeutic counseling since 2010 .

\section{Additional Patient History}

The patient is happily married and has a 5 year old son (spontaneous pregnancy), who was born in September 2006 after an emergency caesarean section due to non-opening of the uterine cervix caused by the turned position of the uterus. The pregnancy had been uncomplicated otherwise. Two years after, a developmental delay and an abnormal EEG suggested a perinatal lack of fetal oxygen supply (with a hypothesized minor left brain damage of the child). Nonetheless, the child has since developed normally and was enrolled in school in 2012.

She is a European academic who has been living in the EU for several years. Height: $167 \mathrm{~cm}$, weight: $50 \mathrm{~kg}$. Her father suffered from a myocardial infarction and has osteoarthritis of the hip, so does her mother. Her only brother is healthy. Her grandparents are in a good health condition.
Table 3. Astha-vidha-pariksha - the eightfold diagnostic approach

\begin{tabular}{ll}
\hline Ayurvedic terminology & Diagnostic method \\
\hline nadi-pariksha & pulse diagnosis \\
mutra-pariksha & urine analysis \\
mala-pariksha & stool analysis \\
jihva-pariksha & tongue diagnosis \\
sabda-pariksha & assessment of bodily sounds, auscultation, \\
& percussion \\
sparsa-pariksha & palpation \\
drk-pariksha & eye assessment \\
akrti & assessment of face and physiognomy \\
\hline
\end{tabular}

Previous Illnesses

Since 2010, she is suffering from chronic joint pain. Since early adulthood she has had recurrent irregular episodes that she relates to a lack of sleep since 1995. Diagnostic tests did not show any specific rheumatologic findings other than the CRP being slightly higher than normal. As a result she has not received a specific diagnosis. She has been intermittently taking low-dosed prednisone based on the advice of her treating physician. Also in 2010, centrofacial rosacea with mild symptoms was diagnosed (minor redness and roughness of both cheeks), but is currently not medically treated. Since 2007, fevers of unknown origin occur (up to $38.6^{\circ} \mathrm{C}$ ), interrupting her daily routine. Despite extensive evaluation by infectious disease, immunology, and rheumatology specialists no clear diagnosis could be determined. In 2009, an overactive immune system was suggested as a diagnosis of exclusion. In 2006, a right-sided hydronephrosis was diagnosed, after her first pregnancy, and treated with stenting and pelvic plastic surgery. Between 2004 and 2005, several drug and pollen allergies were diagnosed. Since 2004, she is suffering from Hashimoto thyroiditis and subsequent substituted hypothyroidism. In 2001, a delayed sleep phase syndrome (DSPS) was diagnosed, with an assumed genetic association to the hPer3-gen (saliva test). From the patient's perspective this is her most problematic health issue that has bothered her since 1995. She suffers from very irregular sleep patterns and is chronically short on sleep and fatigued. The sleep disturbance affects her whole day-to-day life preventing her from 'living in her own rhythm'. She is convinced that the lack of sleep had much to do with her infertility. Since October 2013, she has been in treatment for DSPS and has been advised to sleep from 3.00 a.m. till 11.00 a.m. and to take melatonin orally, which was temporarily stopped during the conventional fertility treatment.

In 1990, she was diagnosed with irritable bowel syndrome (IBS diarrhea), having an intensifying effect on her sleep at night.

1977, she had a nasal polypectomy and 2 years earlier a tonsillectomy.

Medication on First Visit

L-Thyroxin 175 mg 1-0-0; melatonin 3 mg 0-0-1; Tramadol drops (when required); celecoxib $200 \mathrm{mg}$ (when required); levocetirizine $5 \mathrm{mg}$ (when required)

\section{General Ayurvedic Diagnosis}

After thorough patient history taking (prashna) including modern and Ayurvedic parameters, the eightfold and tenfold diagnostic processes (ashta-vidha- and dasha-vidha-pariksha) were performed according to traditional diagnostic principles of Ayurveda $[29,32,38]$ (table 3 ). The patient was given an Ayurvedic diagnosis of vandhyatva based on a vata-pitta constitution (prakrti). The most obvious and relevant pathological findings from the Ayurvedic perspective were: (1) an overall imbalance of all of the 3 main functional principles in Ayurvedic pathophysiology (sannipataprakopa of vata-, pitta- and kapha-dosha), with dominating kinetic 
and thermo-metabolic principles (vata and pitta) and (2) an irregular functioning of the digestive principle (agni). According to the Ayurvedic explanatory model for etiopathogenesis / disease staging (samprapti), the diseases were in the stages of manifestation ( $v y$ $a k t i)$ with chronically differing complications (bheda).

\section{Specific Diagnostic Interpretation According to Ayurveda}

Apart from the general diagnosis, gynecological and diseasespecific diagnostic interpretations were performed, incorporating modern as well as Ayurvedic assessment paradigms: Longstanding menstrual irregularities and associated symptoms like severe dysmenorrhea represent signs of imbalanced gynecological functions (apana-vata-prakopa and arthava-dhatu-dushti); anatomical abnormalities in the gynecological site (vata-prakopa); caesarian section, curettages, miscarriages, intramural pregnancy with iatrogenic abortion, and IVF procedures can be interpreted as traumata in the gynecological area (vata, especially apana-vata), leaving scars and leading to a 'passage block' (sroto-rodha) of apana-vata, the main principle of governing gynecological functions; ovarian cysts (arthava-dhatu-vrddhi and vata-kapha-prakopa) also hindering nidation; and 2 episodes of an ovarian hyperstimulation syndrome (vata-prakopa). Hashimoto thyroiditis, allergies, and lowgrade fever are indicators of a generally disturbed immune system (rasa-kshaya and ojo-vyapat with vata as main active factor) - a situation, which can be interpreted as a disturbed environment for nidation and conception in general. History of drug intake (e.g., MTX, opioids, prednisolone) is another inhibiting factor for natural fertilization according to Ayurveda. IBS represents an imbalance in apana-vata. Her long-lasting sleeping disorder is a primary mental stressor hampering emotional stability, which is a crucial factor for a successful pregnancy according to Ayurveda.

Further, the patient experienced a multitude of factors aggravating chronic stress (e.g., travels and moving her home, onset of chronic diseases, and the fact that the patient has vata as predominant constitutional factor) leading to general aggravation of vata and rajas as well as to a reduction of rasa and ojas. Rasa and ojas are important factors for a successful pregnancy.

Based on the Ayurvedic diagnosis vandhyatva and considering constitutional factors, the following tailored treatment protocol was developed, during an individual 90-min session, and discussed with the patient: constitution- and disease-based dietary (ahara) and lifestyle (vihara) advice including daily intranasal self-massage, gargling, and self-body massage with sesame oil; regular administration of herbs (aushadhi: combination of the fine powders of Withania somnifera, Bacopa monnieri, Asparagus racemosus, and Tinospora cordifolia [39]; one teaspoon $1 \times$ daily of this mixture); nutritional supplements (Chyavanaprasha linctus [40], 1 tablespoon with boiled milk $1 \times$ daily in the morning); Ayurvedic manual therapies $1 \times$ weekly for 90 min over 3 months (full body massage with Maha-Narayana oil [41], abdominal massage with Dhanvantara oil [40], and local oil applications on the lower back (kati-

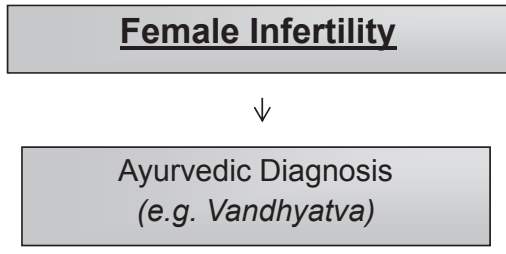

$\downarrow$

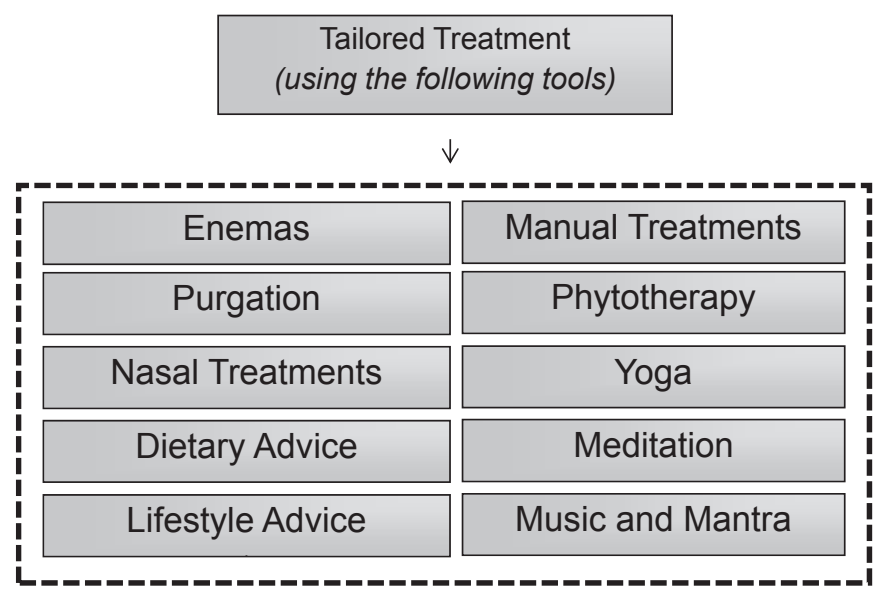

Fig. 1 The Ayurvedic approach in female infertility.

basti) [38]); nasal applications of medicated fats (nasya with brahmi-ghrta [40]) every 2 weeks); and an ambulant purgation therapy (virecana [38]) with $30 \mathrm{ml}$ castor oil in the beginning of the therapeutic sequence followed by medicated enemas (matra-basti [38]) with $20 \mathrm{ml}$ Maha-Narayana oil (to be administered by the patient herself $1-2 \times$ weekly. Moreover, the patient was prescribed 2 individual therapeutic hatha yoga lessons with a focus on grounding postures (asanas) and cooling breathing exercises (pranayama) to be performed daily for 15-30 min at home; further, she was invited to participate in the weekly mantra recitation and mindfulness session at the CAM-Center (fig. 1 and table 4).

At follow-up consultation on December 20, 2011, the patient reported premenstrual syndrome-related complains and an elevated body temperature up to a maximum of $38^{\circ} \mathrm{C}$. She started the therapy according to the protocol, enjoying yoga and currently singing a lot. Takra-dhara was added (constant stream of lukewarm buttermilk dripping onto pressure points on the forehead) to the manual therapy protocol.

The follow-up consultation on January 10, 2012 revealed that the patient was tolerating all Ayurvedic therapies, yet still suffering from poor sleep quality throughout the last weeks. She reported being in a mentally 'good shape' and to 'listen more to her body'. She had no current episodes of fever or infections. The therapeutic measurements remained unchanged, except for 0,5 teaspoon of herbal powder combination daily (as described above and opposed to the previous dosage of 1 teaspoon daily).

The follow-up consultation 8 days later showed that the patient was pregnant in the 4 th week. She reported 'feeling great'. For health and pregnancy maintenance, she was advised to stop the intake of the herbal mixture immediately and to consider an 
Table 4. Concrete therapeutic items in this case

\author{
Prevention and wellness \\ Balancing methods (nutritional therapy and \\ supplements; botanical medicine) \\ Detoxifying therapies (external and internal \\ measures) \\ Psychotherapy, mind-body medicine, yoga, \\ meditation, spiritual aspects, rituals
}

dietary counseling, daily intranasal application of sesame oil, daily gargling with sesame oil, daily self-body-massage Withania somnifera, Bacopa monnieri, Asparagus racemosus, Tinospora cordifolia, Chyavanaprasha linctus weekly manual therapy, local oil applications, nasal applications, medicated purgation therapy, medicated enemas hatha yoga lessons, breathing exercises, mantra recitation, mindfulness sessions upgrade or cancel a planned flight to New Zealand which was scheduled for January 20, in order to reduce stress and exposure to radiation. Due to family reasons, however, the patient decided to fly anyway.

On November 8, 2012, another follow-up consultation took place. Until then, she had given birth to a healthy baby boy on August 20, 2012 via a routine and uncomplicated caesarean section in the 36 th week of pregnancy (birth weight 3,100 g). She reported having had a 'great pregnancy' and 'great birth' without any major health complaints. Upon enquiry, she reported to have had premature labor in the 23rd week and was therefore advised by her treating gynecologist to rest in bed for several weeks in order to become stable. After the birth of her child she had a reoccurrence of fevers up to $38.5^{\circ} \mathrm{C}$, thus we advised her to resume the herbal regimen, manual therapies, and yoga-pranayama.

Since this case was treated in a CAM outpatient department where it was part of a routine Ayurvedic care, no laboratory test or imaging was performed throughout the observational period. No adverse events were reported.

The Ayurvedic herbal products were prescribed by medical doctors and were procured from registered German pharmacies in order to ensure highest quality and safety.

\section{Conclusion and Discussion}

Based on Ayurvedic diagnostic criteria, infertility in the present case is a result of a long-lasting disease process. The holistic Ayurvedic approach includes a multimodal strategy (fig. 1). WMSs like Ayurveda do not represent a mere collection of single and autonomous treatment items but a complex combination of treatments whose functioning can only be understood if viewed as an integrated whole $[42,43]$. An important aspect of the holistic and milieu-oriented Ayurvedic strategy is the therapeutic integration of the somatic, psycho-mental, and spiritual realm [19].

The cleansing methods (purgation and enemas) are delivered to balance the kinetic vata principle, according to the Ayurvedic hermeneutics. The reasons for this are difficult to explain through conventional modern pathophysiological approaches; ostensibly, these methods serve mucosal care, regulate the intestinal microbiota, correct the interior milieu, activate intestinal metabolism and excretion, and counteract side effects of conventional pharmacotherapy. The individual dietary approach also follows the same principles [44-49].
The powdered Ayurvedic herbal drug mixture used in this patient primarily targets adaptogenic, rejuvenative, aphrodisiac, and general strengthening as well as strengthening of the reproductive tissues; it helps enhancing digestion and cognition and has mild anxiolytic and antidepressant properties (W. somnifera [50-55], A. racemosus [56-61], T. cordifolia [62-65], B. monnieri [66-70]).

In a similar way, yoga, meditation, and mantra recitation [7176] address the physical and mental stress caused by the numerous futile fertility attempts with conventional therapy. The reduced quality of life due to prior biomedical treatment is another target of the Ayurvedic therapy. From the Ayurvedic perspective, the mindbody medicine elements also target a regulation of vata, in this case on the level of the mind.

The differentiated massage techniques, including the foreheaddripping therapy (shirodhara) and the nasal treatment (nasya) with precisely selected medicated oils and other substances, further facilitate the stabilization of the overall constitution by balancing the impaired vata principle [77-81].

Overall, the patient's clinical history is marked by a potentially dangerous excess of biomedical therapies to induce pregnancy, each with significant adverse effects. The patient is 38 years old and objectively still in a fertile age. She has already given birth to a child, thus primary sterility can be ruled out a priori (notably the semen analysis of the patient's partner was completely normal). That she consulted several experts and centers in different countries, due to desperation, further contributes to this issue. The numerous and different approaches to get pregnant have been described in the case report section. As a result of this bodily and emotional distress, a reactive secondary sterility might be considered. From an integrative perspective, this proposed diagnosis of secondary sterility can be viewed as a psycho-physical disintegration with a tendency to somatize a psycho-mental conflict aggravated and (partially) caused by medical, technological, and biochemical interventions.

In this light it might also be discussed whether the patient should be considered subfertile instead of infertile. The fact that she got pregnant 3 times after assisted treatment indicates that she would have had good chances of a spontaneous pregnancy if things had progressed differently.

This case might also be of interest from a societal perspective. In the current biomedical paradigm, infertile patients are able (and many times even encouraged by medical personnel) to expose themselves to an almost unlimited number of ART procedures. In this context, several questions regarding the exposure and overex- 
posure of ART procedures appear (e.g., when and who determines that a patient has been exposed to enough attempts in IVF? What about the exposure to potential risks and adverse effects? What are the societal costs of these treatments?)

In modern Western societies the connection between stress and sub-/infertility or even miscarriage is not yet well established. However, it is not uncommon in our practice to see patients who have given up ART and then become pregnant once they manage to address stressors, expectations, and adverse effects of ART treatment itself. Unfortunately, some women will continue the 'fertility search' into extremes and might lose several years of life quality because their only priority is the hope of a pregnancy. Based on this, retrospectively one might ask what would have happened if the patient would have turned to Ayurvedic treatment much earlier. Could she have avoided the 4 stressful years of continuous ART treatment and therefore avoided a potential barrier for conception?

Having all this in mind, several limitations of this case report are worth mentioning. Above all, it remains an open question whether the Ayurvedic approach itself exerted any specific fertility-promoting effect or whether abandoning the conventional treatment in combination with the passage of time were more important factors. Non-specific factors, such as the setting effect and associated context factors might also have created an atmosphere conducive for conception. Moreover, the patient's autoimmune conditions, in particular the Hashimoto thyreoiditis, requiring a high dose of L-thyroxin substitution and accompanied by possible hypothyroid episodes, could probably explain the low chances of nidation and favoring miscarriages. Additionally, the interim stop of the DSPSrelated melatonin intake during the conventional ART created additional stress and a worsened quality of sleep from the patient's perspective, which was yet another potential unspecific confounding factor. The primary dysmenorrhea since the age of 15 is also an issue that raises questions. Severe menstrual pain could be a sign of endometriosis and is a well-known cause of sub- and infertility. Intermittent signs of inflammation and fever as described in this patient could also be explained by endometriosis. Even though a laparoscopic tubar passage has been performed revealing no signs of endometriosis, there is a residual risk remaining.

In summary, the current data for the effectiveness of Ayurvedic interventions is based primarily on rather small and mostly preliminary clinical trials from South Asia [19]. However, Ayurvedic medicine as a WMS has been practiced in South Asia for more than 2000 years, and as such this long history of practice should be considered when evaluating its potential effects, as in this case report. From the perspective of modern scientific research, further research is warranted. In particular, studies on effectiveness and safety as well as fields of use of herbal medicines should be conducted with regard to significance of context and setting factors in Ayurvedic therapies.

As is described in this case, integration of Ayurvedic treatments into modern medical strategies for fertility has the potential to improve patient outcomes [82, 83].

\section{Acknowledgment}

We are thankful to our patient for the indispensable reconstruction of her case history and, most of all, for her willingness to use her anonymized data for this publication. Thanks also to Prof. Shivenarain Gupta for this very valuable advice.

\section{Disclosure Statement}

The authors declare that there are no competing interests.

\section{References}

1 World Health Organization (WHO): Current pratices and controversies in assisted reproduction: Report of a WHO meeting; in Vayena E, Rowe PJ, Griffin PD (eds): Medical, Ethical and Social Aspects of Assisted Reproduction. Genevea, WHO Publications, 2002, pp 381-396.

2 Brandes M, Hamilton CJ, van der Steen JO, de Bruin JP, Bots RS, Nelen WL, Kremer JA: Unexplained infertility: overall ongoing pregnancy rate and mode of conception. Hum Reprod 2011;26:360-368.

3 van Dongen AJ, Verhagen TE, Dumoulin JC, Land JA, Evers JL: Reasons for dropping out from a waiting list for in vitro fertilization. Fertil Steril 2010;94:1713-1716.

4 Diedrich K, Ludwig M, Griesinger G: Reproduktionsmedizin. Berlin, Springer, 2013

5 van Kasteren YM, Schoemaker J: Premature ovarian failure: a systematic review on therapeutic interventions to restore ovarian function and achieve pregnancy. Hum Reprod Update 1999;5:483-492.

6 Zafeiriou S, Loutradis D, Michalas S: The role of gonadotropins in follicular development and their use in ovulation induction protocols for assisted reproduction. Eur J Contracept Reprod Health Care 2000;5:157-167.
7 Leidenberger F, Strowitzki T, Ortmann O: Störungen des Prolaktinhaushalts; in dies. (eds): Klinische Endokrinologie für Frauenärzte. Heidelbergm, Springer, 2005.

8 Eisenhardt S, Schwarzmann N, Henschel V, Germeyer A, von Wolff M, Hamann A, Strowitzki T: Early effects of metformin in women with polycystic ovary syndrome: a prospective randomized, double-blind, placebo-controlled trial. J Clin Endocrinol Metab 2006;91: 946-952.

9 Schäfer-Graf UM, Kleinwechter H: Insulinresistenz vor und während der Schwangerschaft. Frauenarzt 2007;48:226-233.

10 Licht P: Behandlung der Sterilität; in Wacker J, Sillem M, Bastert G, Beckmann MW (eds): Therapiehandbuch Gynäkologie und Geburtshilfe. Heidelberg, Springer, 2007, pp 224-235.

11 Strowitzki T: Indikationsbereiche IVF versus ICSI. Gynäkologe 2000;33:777-781.

12 Scheidel P, Hepp H, De Cherney AH: Operative Techniken der Reproduktionsmedizin. München, Urban und Schwarzenberg, 1999.

13 Sperling H, Lümmen G, Rübben H: Rationelle Therapie bei unerfülltem Kinderwunsch aus urologischer Sicht. Urologe 1996;36:345-347.
14 van den Broeck U, Emery M, Wischmann T, Thorn P: Counseling in infertility: individual, couple and group interventions. Patient Educ Couns 2010;81:422-428.

15 Steptoe PC, Edwards RG: Birth after preimplantation of a human embryo. Lancet 1978;2:366.

16 Deutsches IVF-Register e.V. www.deutsches-ivf-register. de (accessed 14.07.2015).

17 Palermo G, Joris H, Devroey P, Van Steirteghem AC: Pregnancies after intracytoplasmic injection of single spermatozoon into an oocyte. Lancet 1992;340:17-18.

18 Kowalcek I: Medizinische Risikobelastung während Schwangerschaft und Geburt für Mütter und Kinder; in Kentenich H, Brähler E, Kowalcek I, Strauß B, Thorn P, Welbus AJ, Wischmann T, Stöbel-Richter: Leitlinie psychosomatisch orientierte Diagnostik und Therapie bei Fertilitätsstörungen. Gießen, Psychosozial-Verlag, 2014.

19 Witt CM, Michalsen A, Roll S, Morandi A, Gupta S, Rosenberg M, Kronpass L, Stapelfeldt E, Hissar S, Muller M, Kessler C: Comparative effectiveness of a complex Ayurvedic treatment and conventional standard care in osteoarthritis of the knee - study protocol for a randomized controlled trial. Trials 2013;14:149. 
20 Capra F: The Web of Life: A New Scientific Understanding of Living Systems. New York, Anchor Books, 1996.

21 Bell IR: Models for the study of whole systems. Integr Cancer Ther 2006;5:293-307.

22 World Health Organization (WHO): Traditiona Medicine. Report by the Secretariat. A 56/18. 2003. https:// extranet.who.int/iris/restricted/handle/10665/78244 (accessed 14.07.2015).

23 World Health Organization: Traditional Medicine in Asia. New Delhi, WHO Regional Publications, 2002.

24 Kessler C: Wirksamkeit von Ayurveda bei chronischen Erkrankungen. Systematische Analysen klinischer Ayurveda-Studien. Essen, KVC, 2007.

25 Association of Ayurvedic Physicians of India. www. apiindia.org (accessed 21.07.2015).

26 World Health Organization (WHO): Benchmarks for Training in Traditional / Complementary and Alternative Medicine: Benchmarks for Training in Ayurveda. Geneva, WHO, 2010.

27 Morandi A, Tosto C, Roberti di Sarsina P, Dalla Libera D: Salutogenesis and Ayurveda: indications for public health management. EPMA J 2011;2:459-465.

28 Antonovsky A: Health, Stress and Coping. San Francisco, Jossey-Bass, 1979

29 Gupta SN, Stapelfeld E: Praxis in der Ayurveda. Medizin. Kaya-cikitsa. Therapiekonzepte für innere Erkrankungen. Stuttgart, Haug, 2009.

30 Morandi A, Tosto C: Ayurveda, the paradigm for personalized medicine. EPMA J 2011;2:151-152.

31 Kessler CS, Ostermann T, Meier L, Stapelfeldt E Schutte S, Duda J, Michalsen A: Additive complex Ayurvedic treatment in patients with fibromyalgia syndrome compared to conventional standard care alone: a nonrandomized controlled clinical pilot study (KAFA Trial). Evid Based Complement Alternat Med 2013, 2013:751403.

32 Dash V, Sharma RK: Caraka Samhita: Text with English Translation and Critical Exposition Based on Cakrapani Datta's Ayurveda Dipika. New Delhi, Chaukhamba Sanskrit Series Office, 2001.

33 Anonymous: Sushruta Samhita: With English Translation of Text and Dalhana's Commentary along with Critical Notes; edited and translated by Priya Vrat Sharma. Varanasi, Chaukhamba Visvabharati, 2001.

34 Board of Scholars: Astangahrdaya Samhita of Vagbhata. The Book of Eight Branches of Ayurveda. New Delhi, Vedams, 1999

35 Tewari P: Kashyapa-Samhita - Ayurvediya Prasutitantra evam Striroga. Chaukhambha Orientalia, part 2 chapter 5, ed 2. Varanasi, Chaukhamba, 2000.

-36 Shukla Upadhyaya K, Karunagoda K, Dei LP: Infertility caused by tubal blockage: an Ayurvedic appraisal. Ayu 2010;31:159-166.

37 Babu G, Babu A, Bhuyan GC, Prasad GP, Swamy GK: Vandhyatva - a medico historical study. Bull Indian Inst Hist Med Hyderabad 2006;36:83-96.

38 Lad V: Textbook of Ayurveda. Albuquerque, Ayurvedic Press, 2002.

39 Anonymous: The Ayurvedic Formulary of India, part 1. New Delhi, Civil Lines, 1978.

40 Anonymous: The Ayurvedic Pharmacopoeia of India, part II, vol. II. New Delhi, Civil Lines, 2008.

41 Misra BSB: Bhaishajya ratnavali of Sri Govinda Das. Varanasi, Chowkamba Prakashan, 2007.

42 Auyang SY: Foundations of Complex-system Theories: in Economics, Evolutionary Biology, and Statistical Physics. Cambridge, Cambridge University Press, 1999.

43 Oshry B: Seeing Systems: Unlocking the Mysteries of Organizational Life. San Francisco, Berrett-Koehler 2008.

44 Conboy L, Edshteyn I, Garivaltis H: Ayurveda and Panchakarma: measuring the effects of a holistic health intervention. Scientific World Journal 2009; 9:272-280.
45 Donga KR, Donga SB, Dei LP: Role of Nasya and Matra Basti with Narayana Taila on anovulatory fac tor. Ayu 2013;34:81-85.

46 Gupta PK, Sigh RH: A conceptual study on vasti effect. Anc Sci Life 2001; 20:54-59.

47 Sharma H, Chandola HM, Singh G, Basisht G: Utilization of Ayurveda in health care: an approach for prevention, health promotion, and treatment of disease. Part 2 - Ayurveda in primary health care. J Altern Complement Med 2007;13:1135-1150.

48 Shukla G, Bhatted SK, Dave AR, Shukla VD: Efficacy of Virechana and Basti Karma with Shamana therapy in the management of essential hypertension: a comparative study. Ayu 2013;34:70-76.

49 Poehlmann A: Practice of pancakarma in Western countries - a German experience. Anc Sci Life 1996;16: 103-107.

50 Anonymous: Monograph. Withania somnifera. Altern Med Rev 2004;9:211-214.

51 Mahajan GK, Mahajan AY, Mahajan RT: Efficacy of aphrodisiac plants towards improvement in semen quality and motility in infertile males. J Complement Integr Med 2012;9:Article 6.

52 Mahdi AA, Shukla KK, Ahmad MK, Rajender S, Shankhwar SN, Singh V, Dalela D: Withania somnifera improves semen quality in stress-related male fertility. Evid Based Complement Alternat Med 2009;29:Epub ahead of print.

53 Mirjalili MH, Moyano E, Bonfill M, Cusido RM, Palazon J: Steroidal lactones from Withania somnifera, an ancient plant for novel medicine. Molecules 2009; 14: 2373-2393.

54 Vanden Berghe W, Sabbe L, Kaileh M, Haegeman G, Heyninck K: Molecular insight in the multifunctional activities of Withaferin A. Biochem Pharmacol 2012; 84:1282-1291.

55 Singh N, Bhalla M, de Jager P, Gilca M: An overview on ashwagandha: a Rasayana (rejuvenator) of Ayurveda. Afr J Tradit Complement Altern Med 2011;8: 208-213.

56 Gaitonde BB, Jetmalani MH: Antioxytocic action of saponin isolated from Asparagus racemosus (Shatavari) on uterine muscle. Arch Int Pharmacodyn Ther 1969; 179:121-129.

57 Goyal RK, Singh J, Lal H: Asparagus racemosus - an update. Indian J Med Sci 2003;57:408-414.

58 Saxena S, Bopana N: In vitro clonal propagation of Asparagus racemosus, a high value medicinal plant. Methods Mol Biol 2009;547:179-189.

59 Rege NN, Thatte UM, Dahanukar SA: Adaptogenic properties of six rasayana herbs used in Ayurvedic medicine. Phytother Res 1999;13:275-291.

60 Sharma S, Ramji S, Kumari S, Bapna JS: Randomized controlled trial of Asparagus racemosus (Shatavari) as a lactogogue in lactational inadequacy. Indian Pediatr 1996;33:675-677.

61 Sharma P, Chauhan PS, Dutt P, Amina M, Suri KA, Gupta BD, Suri OP, Dhar KL, Sharma D, Gupta V, Satti NK: A unique immuno-stimulant steroidal sapogenin acid from the roots of Asparagus racemosus. Steroids 2011;76:358-364.

62 Panchabhai TS, Kulkarni UP, Rege NN: Validation of therapeutic claims of Tinospora cordifolia: a review. Phytother Res 2008;22:425-441.

63 Saha S, Ghosh S: Tinospora cordifolia: one plant, many roles. Anc Sci Life 2012;31:151-159.

64 Spelman K, Burns J, Nichols D, Winters N, Ottersberg S, Tenborg M: Modulation of cytokine expression by traditional medicines: a review of herbal immunomodulators. Altern Med Rev 2006;11:128-150.
65 Upadhyay AK, Kumar K, Kumar A, Mishra HS: Tinospora cordifolia (Willd.) Hook. f. and Thoms. (Guduchi) - validation of the Ayurvedic pharmacology through experimental and clinical studies. Int J Ayurveda Res 2010,;1:112-121.

66 Anonymous: Bacopa monniera. Monograph. Altern Med Rev 2004;9:79-85.

67 Singh HK: Brain enhancing ingredients from Ayurvedic medicine: quintessential example of Bacopa monniera, a narrative review. Nutrients 2013;5:478-497.

68 Kidd PM: A review of nutrients and botanicals in the integrative management of cognitive dysfunction. Altern Med Rev 1999;4:144-161.

69 Kongkeaw C, Dilokthornsakul P, Thanarangsarit P, Limpeanchob N, Norman Scholfield C: Meta-analysis of randomized controlled trials on cognitive effects of Bacopa monnieri extract. J Ethnopharmacol 2014;151: 528-535.

70 Russo A, Borrelli F: Bacopa monniera, a reputed nootropic plant: an overview. Phytomedicine 2005; 12 : 305-317

71 Brotto LA, Mehak L, Kit C: Yoga and sexual functioning: a review. J Sex Marital Ther 2009;35:378-390.

72 Brotto LA, Krychman M, Jacobson P: Eastern approaches for enhancing women's sexuality: mindfulness, acupuncture, and yoga (CME). J Sex Med 2008;5: 2741-2748;quiz 2749.

73 Rani K, Tiwari S, Singh U, Singh I, Srivastava N: Yoga Nidra as a complementary treatment of anxiety and depressive symptoms in patients with menstrual disorder. Int J Yoga 2012;5:52-56.

74 Rani K, Tiwari SC, Singh U, Agrawal GG, Srivastava N: Six-month trial of Yoga Nidra in menstrual disorder patients: effects on somatoform symptoms. Ind Psychiatry J 2011;20:97-102.

75 Bernardi L, Sleight P, Bandinelli G, Cencetti S, Fattorin L, Wdowczyc-Szulc J, Lagi A: Effect of rosary prayer and yoga mantras on autonomic cardiovascular rhythms: comparative study. BMJ 2001;323:1446-1449.

76 Monika, Singh U, Ghildiyal A, Kala S, Srivastava N: Effect of Yoga Nidra on physiological variables in patients of menstrual disturbances of reproductive age group. Indian J Physiol Pharmacol 2012;56:161-167.

77 Vinjamury SP, Vinjamury M, der Martirosian C, Miller J: Ayurvedic therapy (shirodhara) for insomnia: a case series. Glob Adv Health Med 2014;3:75-80.

78 Xu F, Uebaba K, Ogawa H, Tatsuse T, Wang BH, Hisajima T, Venkatraman S: Pharmaco-physio-psychologic effect of Ayurvedic oil-dripping treatment using an essential oil from Lavendula angustifolia. J Altern Complement Med 2008;14:947-956.

79 Stoelzel K, Bothe G, Chong PW, Lenarz M: Safety and efficacy of Nasya/Prevalin in reducing symptoms of allergic rhinitis. Clin Respir J 2014;8:382-390.

80 Uebaba K, Xu FH, Ogawa H, Tatsuse T, Wang BH, Hisajima T, Venkatraman S: Psychoneuroimmunologic effects of Ayurvedic oil-dripping treatment. J Altern Complement Med 2008;14:1189-1198.

81 Dhuri KD, Bodhe PV, Vaidya AB: Shirodhara: a psycho-physiological profile in healthy volunteers. J Ayurveda Integr Med 2013;4:40-44.

82 Kessler C, Wischnewsky M, Michalsen A, Eisenmann C, Melzer J: Ayurveda: between religion, spirituality, and medicine. Evid Based Complement Alternat Med 2013;2013:952432.

83 Kronpass L, Krampol S, Brattinger P, Stapelfeldt E, Kessler C: Integrative management using Ayurvedic medicine in a patient with advanced malignant mixed Muellerian tumor - a case report. Forsch Komplementmed 2014;21:48-53. 